\title{
ZO-1 and the Spatial Organization of Gap Junctions and Glutamate Receptors in the Outer Plexiform Layer of the Mammalian Retina
}

\author{
Christian Puller, ${ }^{1}$ Luis Pérez de Sevilla Müller, ${ }^{2}$ Ulrike Janssen-Bienhold, ${ }^{2}$ and Silke Haverkamp ${ }^{1}$ \\ ${ }^{1}$ Department of Neuroanatomy, Max Planck Institute for Brain Research, D-60528 Frankfurt, Germany, and 2Department of Neurobiology, University of \\ Oldenburg, D-26111 Oldenburg, Germany
}

\begin{abstract}
Information processing in the retina starts at the first synaptic layer, where photoreceptors and second-order neurons exhibit a complex architecture of glutamatergic and electrical synapses. To investigate the composition of this highly organized synaptic network, we determined the spatial relationship of zonula occludens-1 (ZO-1) with different connexins $(\mathrm{Cx})$ and glutamate receptor (GluR) subunits in the outer plexiform layer (OPL) of rabbit, mouse, and monkey retinas. ZO-1 is well known as an intracellular component of tight and adherens junctions, but also interacts with various connexins at gap junctions. We found Z0-1 closely associated with $\mathrm{Cx} 50$ on dendrites of A-type horizontal cells in rabbit, and with $\mathrm{Cx} 57$ at dendro-dendritic gap junctions of mouse horizontal cells. The spatial arrangement of ZO- 1 at the giant gap-junctional plaques in rabbit was particularly striking. Z0-1 formed a clear margin around the large Cx50 plaques instead of being colocalized with the connexin staining. Our finding suggests the involvement of ZO-1 in the composition of tight or adherens junctions around gap-junctional plaques instead of interacting with connexins directly. Furthermore, gap junctions were found to be clustered in close proximity to GluRs at the level of desmosome-like junctions, where horizontal cell dendrites converge before invaginating the cone pedicle. Based on this distinct spatial organization of gap junctions and GluRs, it is tempting to speculate that glutamate released from the photoreceptors may play a role in modulating the conductance of electrical synapses in the OPL.
\end{abstract}

\section{Introduction}

Retinal processing begins in the outer plexiform layer, where cone pedicles and rod spherules provide multiple output synapses onto bipolar and horizontal cells. Synaptic transmission is mediated by glutamate and metabotropic or ionotropic glutamate receptors (GluRs) (for review, see Wässle, 2004), and by electrical coupling of different cell types via connexins (for review, see Söhl et al., 2005). These components are accompanied by different scaffolding proteins and further cell-cell contacts to stabilize the synaptic organization of the neuronal network.

Some of the proteins involved in these complex synapses and their location in the OPL have already been analyzed, but the question regarding their spatial relations to each other remains open. To address this question and to analyze whether the synaptic architecture in the OPL is conserved between mammalian species, we investigated the expression patterns of the scaffolding protein zonula occludens-1 ( $\mathrm{ZO}-1)$, different connexins $(\mathrm{Cx})$, and GluRs on horizontal cells of rabbit, mouse, and monkey retinas.

\section{Received Dec. 10, 2008; revised March 20, 2009; accepted April 12, 2009.}

This study was supported by a grant of the Deutsche Forschungsgemeinschaft (FOR 701, PE 38/16-1). We thank B. Marshallsay, G.-S. Nam, and W. Hofer for excellent technical assistance, J. Nathans for providing the S-opsin antibody, and J. Trümpler for editing this manuscript. We give special thanks to $H$. Wässle for his continuous support and input.

Correspondence should be addressed to Silke Haverkamp, Max-Planck-Institut für Hirnforschung, Deutschordenstrasse 46, D-60528 Frankfurt/Main, Germany. E-mail: haverkamp@mpih-frankfurt.mpg.de.

D0I:10.1523/JNEUROSC1.5867-08.2009

Copyright $\odot 2009$ Society for Neuroscience $\quad$ 0270-6474/09/296266-10\$15.00/0
Horizontal cells are homologously coupled by gap junctions, forming an extensive network that feeds back onto the photoreceptors. Because of this electrical coupling, each horizontal cell receives photoreceptor input over a receptive field that is much larger than its dendritic field (Kaneko, 1971), and the spatial extent of the feedback signal is determined, in part, by the strength of coupling in the horizontal cell network (Dacheux and Raviola, 1982; Bloomfield et al., 1995). Horizontal cell coupling is regulated by ambient light (Xin and Bloomfield, 1999) via neuromodulators such as dopamine and retinoic acid (Teranishi et al., 1983; Perlman and Ammermüller, 1994; He et al., 2000; Pottek and Weiler, 2000). Horizontal cells in mouse are coupled by gap junctions composed of Cx57 (Hombach et al., 2004; Shelley et al., 2006; Janssen-Bienhold et al., 2009); A-type horizontal cells in rabbit retina are coupled by Cx50 (O’Brien et al., 2006). Furthermore, numerous proteins have been identified that may be involved in the mechanism of gap-junctional coupling. For instance, ZO-1 has been found at gap junctions, interacting with several different connexins (for review, see Giepmans, 2004). However, the structural role of ZO-1 is unclear. Studies in mouse retina revealed an association of $\mathrm{ZO}-1$ with $\mathrm{Cx} 36$ in both the OPL and the inner plexiform layer (IPL), and with Cx45 in the IPL (Li et al., 2004, 2008; Ciolofan et al., 2006, 2007).

In the present study, we found that $\mathrm{ZO}-1$ was colocalized with $\mathrm{Cx} 36$ at rod spherules and at the cone pedicle base in all three species. However, ZO-1 was also clustered in close proximity to GluRs at desmosome-like junctions between horizontal cell dendrites. Here, ZO-1 was colocalized with Cx50 on A-type horizon- 
Table 1. Primary antibodies used in this study

\begin{tabular}{|c|c|c|c|}
\hline Antibody & Species, type, working dilution & Immunogen & Source, catalog number \\
\hline $\mathrm{CaBP}$ & Mouse, monoclonal, 1:2000 & Calbindin D-28k from chicken gut & Swant, 300 \\
\hline Cx36 & Rabbit, polyclonal, 1:100 & Synthetic C-terminal peptide of human Connexin 36 & Zymed, $36-4600$ \\
\hline $\mathrm{Cx} 50$ & Rabbit, polyclonal, 1:100 & $\begin{array}{l}\text { Synthetic C-terminal peptide of mouse and rat Connexin 40; antibody } \\
\text { recognizes (x50 in rabbit and cat ( } 0 \text { 'Brien et al., 2006) }\end{array}$ & Millipore Bioscience Research Reagents, AG634 \\
\hline Cx57 & Rabbit, polyclonal, 1:100 & $\begin{array}{l}\text { Synthetic C-terminal peptide of mouse Connexin } 57 \\
\text { (CSMSMILELSSIMKK) (Janssen-Bienhold et al., 2009) }\end{array}$ & $\begin{array}{l}\text { U. Janssen-Bienhold, University of Oldenburg, } \\
\text { Oldenburg, Germany }\end{array}$ \\
\hline Cx57 & Rabbit, polyclonal, 1:100 & $\begin{array}{l}\text { Synthetic peptide from an internal region of mouse, rat, and hamster } \\
\text { Connexin } 57\end{array}$ & Zymed, $40-5000$ \\
\hline GluR2/3 & Rabbit, polyclonal, 1:100 & C-terminal peptide of rat GluR2 (EGYNVYGIESVKI) & Millipore Bioscience Research Reagents, AB1506 \\
\hline GluR4 & Rabbit, polyclonal, 1:100 & C-terminal peptide of rat GluR4 (RQSSGLAVIASDLP) & Millipore Bioscience Research Reagents, AB1508 \\
\hline GluR5 & Goat, polyclonal, 1:100 & C-terminal peptide of human GluR5 (KLIREERGIRKQSSVHTV) & Santa Cruz Biotechnology, SC-7616 \\
\hline GluR6/7 & Rabbit, polyclonal, 1:1000 & C-terminal peptide of rat GluR6 (KHTFNDRRLPGKETMA) & Sigma, G 7669 \\
\hline Parvalbumin & Rabbit, polyclonal, 1:1000 & Rat muscle parvalbumin & Swant, PV-28 \\
\hline PSD-95 & Mouse, monoclonal (7E3-1B8), 1:5000 & Recombinant rat PSD-95 & Affinity BioReagents, MA1-046 \\
\hline S-opsin JH455 & Rabbit, polyclonal, 1:100 & C-terminal peptide of human blue-sensitive opsin (Wang et al., 1992) & $\begin{array}{l}\text { J. Nathans, Johns Hopkins University School of } \\
\text { Medicine, Baltimore, MD }\end{array}$ \\
\hline Z0-1 & Rabbit, polyclonal, 1:500 & $\begin{array}{l}\text { Fusion protein corresponding to amino acids } 463-1109 \text { of human } \\
\text { zonula occludens-1 cDNA }\end{array}$ & Zymed, $61-7300$ \\
\hline Z0-1 & Mouse, monoclonal, 1:100 & $\begin{array}{l}\text { Amino acids } 334-634 \text { of human recombinant zonula occludens-1 } \\
\text { fusion protein }\end{array}$ & Zymed, 33-9100 \\
\hline
\end{tabular}

tal cells in rabbit, and with Cx57 at dendro-dendritic gap junctions of mouse horizontal cells. GluRs at the desmosome-like junctions 1-2 $\mu \mathrm{m}$ below the cone pedicles are thought to be activated by glutamate released from the cone pedicle, with each side of the junction corresponding to a postsynaptic density (Haverkamp et al., 2000).

We also studied the spatial relationship of Cx50 and ZO-1 at giant gap-junctional plaques of A-type horizontal cells in rabbit and found that $\mathrm{ZO}-1$ encloses the $\mathrm{Cx} 50$ plaques, rather than directly colocalizing with the connexin staining.

\section{Materials and Methods}

Animals and tissue preparation

Wild-type mice (C57BL/6J) were deeply anesthetized with isoflurane and decapitated before tissue dissection. Macaque monkeys (Macaca fascicularis) and rabbits (Chinchilla Bastard) were killed by an overdose of pentobarbitone $(100 \mathrm{mg} / \mathrm{kg})$ given intravenously in experiments not related to the present study, and the eyes were enucleated postmortem. All procedures were approved by the local animal care committee and were in accordance with the law for animal experiments issued by the German government (Tierschutzgesetz).

The posterior eyecups were immersion fixed in 2 or $4 \%$ paraformaldehyde (PFA) in $0.1 \mathrm{~m}$ phosphate buffer (PB), pH 7.4, for 10-30 min at room temperature. Following fixation, retinas were dissected from the eyecup, cryoprotected in graded sucrose solutions $(10,20,30 \% \mathrm{w} / \mathrm{v})$, and stored at $-20^{\circ} \mathrm{C}$ in $30 \%$ sucrose until use. Retinal pieces were either used as a whole mount or sectioned vertically at $16 \mu \mathrm{m}$ using a cryostat.

Antibodies and light microscopic immunocytochemistry

The primary antibodies used in the present study are listed in Table 1.

Immunocytochemical labeling was performed using the indirect fluorescence method. Sections were incubated overnight with primary antibodies in $5 \%$ normal donkey serum (NDS), $1 \%$ bovine serum albumin (BSA), $0.5 \%$ Triton X-100, and $0.02 \%$ sodium azide in PB. After washing in $\mathrm{PB}$, secondary antibodies were applied for $1 \mathrm{~h}$. These were conjugated either to Cy3 (Dianova), or Alexa TM 488 (Invitrogen). Retinal pieces were incubated freely floating for $2 \mathrm{~d}$ in a mixture of primary antibodies containing 5\% NDS, $1 \%$ BSA, and $1 \%$ Triton X-100, followed by a $3 \mathrm{~h}$ incubation in a mixture of secondary antibodies.

Confocal photomicrographs were taken using a Zeiss LSM 5 Pascal confocal microscope equipped with an argon and an HeNe laser. Highresolution scanning of image stacks was performed with a PlanApochromat $63 \times / 1.40$ oil-immersion objective at $1024 \times 1024$ pixels and a $z$-axis increment of $0.32 \mu \mathrm{m}$. When projections of image stacks are shown, 3-5 serial optical sections were collapsed into a single plane. Brightness and contrast of the final images were adjusted using Adobe Photoshop CS v8.0.1.

\section{Microinjections}

Isolated pieces of retinas of C57BL/6J mice were incubated in Ames solution ( $\mathrm{pH} 7.4$, Sigma) containing $10 \mu \mathrm{m}$ DAPI (Sigma) for $60 \mathrm{~min}$ at room temperature and mounted on filter paper (Millipore) with ganglion cell layer up.

Horizontal cells were microinjected with $2 \%$ Lucifer yellow (Sigma) and $4 \%$ Neurobiotin (Vector Laboratories) as previously described by Shelley et al. (2006). After injection, pieces were fixed in 4\% PFA in PB for $15 \mathrm{~min}$. To visualize the Neurobiotin, the tissue was incubated with Cy3-conjugated streptavidin (Dianova) overnight in PB and 1\% Triton $\mathrm{X}-100$ at $4^{\circ} \mathrm{C}$. Subsequently, the retinal pieces were labeled with antibodies against $\mathrm{ZO}-1$, following the protocol as described above.

\section{Preembedding immunoelectron microscopy}

Preembedding immunoelectron microscopy was carried out on vibratome sections as described in detail previously (Sassoè-Pognetto et al., 1994). After preincubation in PBS containing 10\% normal goat serum (NGS) and $1 \%$ BSA, vibratome sections were incubated for $4 \mathrm{~d}$ at $4^{\circ} \mathrm{C}$ in primary antibodies diluted in 3\% NGS and 1\% BSA in PBS.

\section{Postembedding immunoelectron microscopy}

The slam-freezing and cryosubstitution methods used in this study are a modification of those previously described (Baude et al., 1993). Briefly, small pieces of retina were slam-frozen onto a precooled copper block using a Reichert MM80 unit (Leica). The frozen specimens were then transferred to a cryosubstitution unit (Reichert AFS; Leica) and placed into a solution of $0.5 \%$ uranyl acetate $(\mathrm{w} / \mathrm{v})$ in $100 \%$ methanol at $-90^{\circ} \mathrm{C}$. After $36 \mathrm{~h}$, the temperature was increased stepwise to $-30^{\circ} \mathrm{C}$. The samples were then washed several times in precooled methanol and then progressively infiltrated with Lowicryl HM20 (Chemische Werke Lowi; 1:1 Lowicryl to methanol, 90 min; 2:1 Lowicryl to methanol, 90 min; 100\% Lowicryl, 90 min; 100\% Lowicryl, overnight). Polymerization was achieved by exposure to UV light for $12 \mathrm{~h}$.

Ultrathin sections were cut and collected on Formvar-coated nickel grids. The sections were first incubated in $0.05 \mathrm{~m}$ Tris-buffered saline (TBS), pH 7.6, for $15 \mathrm{~min}$, followed by a blocking solution containing $10 \%$ NGS and TBS with $0.1 \%$ Triton (TBST) for $20 \mathrm{~min}$. Sections were then incubated overnight in primary anti-GluR2/3 diluted $1: 10$ or anti-GluR4 diluted 1:5 in 1\% NGS and TBST. After washing in TBS, sections were incubated for $2 \mathrm{~h}$ in secondary anti-rabbit IgG conjugated to $10 \mathrm{~nm}$ gold (ICN Biomedicals) diluted 1:20 in 1\% NGS and 
TBST. After further washing in TBS and PB, the sections were fixed for $5 \mathrm{~min}$ in $2 \%$ glutaraldehyde in $\mathrm{PB}$, washed in distilled water, and counterstained with uranyl acetate and lead citrate. The grids were then viewed with a Zeiss EM10 electron microscope.

\section{Results}

Zonula occludens-1 expression in the mammalian retina

The overall ZO-1 expression pattern in rabbit and macaque monkey retina (Fig. 1) appeared very similar to that seen in the mouse retina ( $\mathrm{Li}$ et al., 2004; Ciolofan et al., 2006, 2007) (Fig. 1A). We found strong ZO-1 immunoreactivity at the outer limiting membrane (OLM), and punctate staining in the OPL and IPL. Furthermore, the tight junctions between endothelial cells of the blood vessels were labeled in mouse and monkey retina, and also some amacrine cell bodies in the inner nuclear layer (INL) showed immunoreactivity. In these animals, the ZO-1-immunoreactive puncta in the OPL were densely clustered in regular arrays, most likely below the pedicles of cone photoreceptors. In rabbit retina, the clustering at cone pedicles was not as obvious as in the two other species, but large plaques of ZO-1 immunoreactivity were observed in the proximal part of the OPL. The plaques in the rabbit retina pointed to an expression of ZO-1 by horizontal cells, whose dendrites are present at those sites in the OPL.

ZO-1 forms margins around gap junctions of A-type horizontal cells in rabbit

In rabbit retina, as in many mammalian species, there are two types of horizontal cells named A-type and B-type cells. A-type horizontal cells are axonless with large asymmetric dendrites that contact cones. B-type cells have numerous, symmetrical dendrites that also contact cones, and a long axon that expands into an elaborate axon terminal which selectively contacts rods (Bloomfield and Miller, 1982; Dacheux and Raviola, 1982). In the OPL of the rabbit retina, large ZO-1immunoreactive plaques and smaller puncta were colocalized with A-type horizontal cells at the sites where their dendrites cross (Fig. 2A,B). A-type horizontal cells were labeled with antibodies against the calcium-binding protein calbindin (CaBP) (Röhrenbeck et al., 1987). Interestingly, the staining pattern of ZO-1 and $\mathrm{CaBP}$ in the proximal part of the rabbit OPL, as shown here, closely resembles the
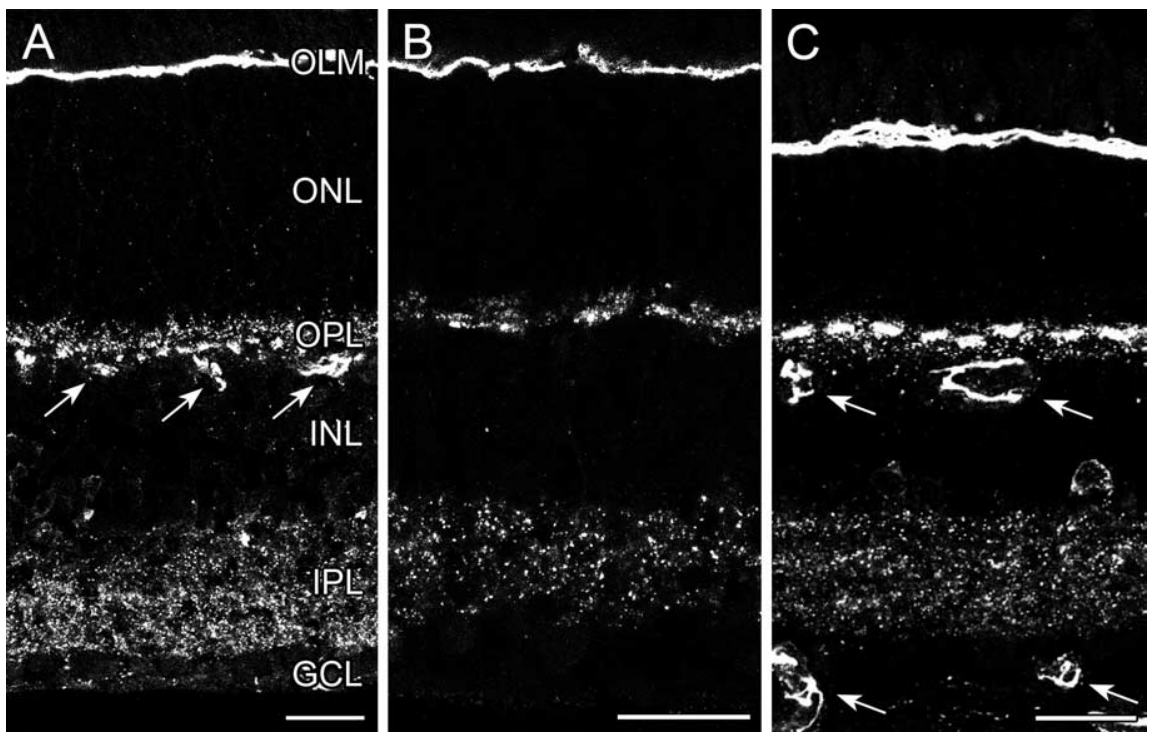

Figure 1. Expression pattern of ZO- 1 in the mammalian retina. $A-C$ show projections of image stacks of vertical cryostat sections labeled with antibodies against Z0-1 in mouse $(\boldsymbol{A})$, rabbit $(\boldsymbol{B})$, and monkey $(\boldsymbol{C})$ retinas. Retinal Z0-1 expression is similar among the three species: the outer limiting membrane (OLM) is strongly labeled and punctate $20-1$ staining is found throughout the outer and inner plexiform layers (OPL, IPL). While the whole IPL is labeled homogeneously, Z0-1 in the OPL is also densely clustered in regular arrays most likely at cone pedicles; this is particularly apparent in the monkey retina. In the inner nuclear layer (INL) and the ganglion cell layer (GCL), Z0-1 is located at tight junctions between vascular endothelial cells (arrows). Furthermore, cell bodies of amacrine cells were labeled in the INL of monkey and mouse retinas (ONL, outer nuclear layer). Scale bars: $20 \mu \mathrm{m}$.
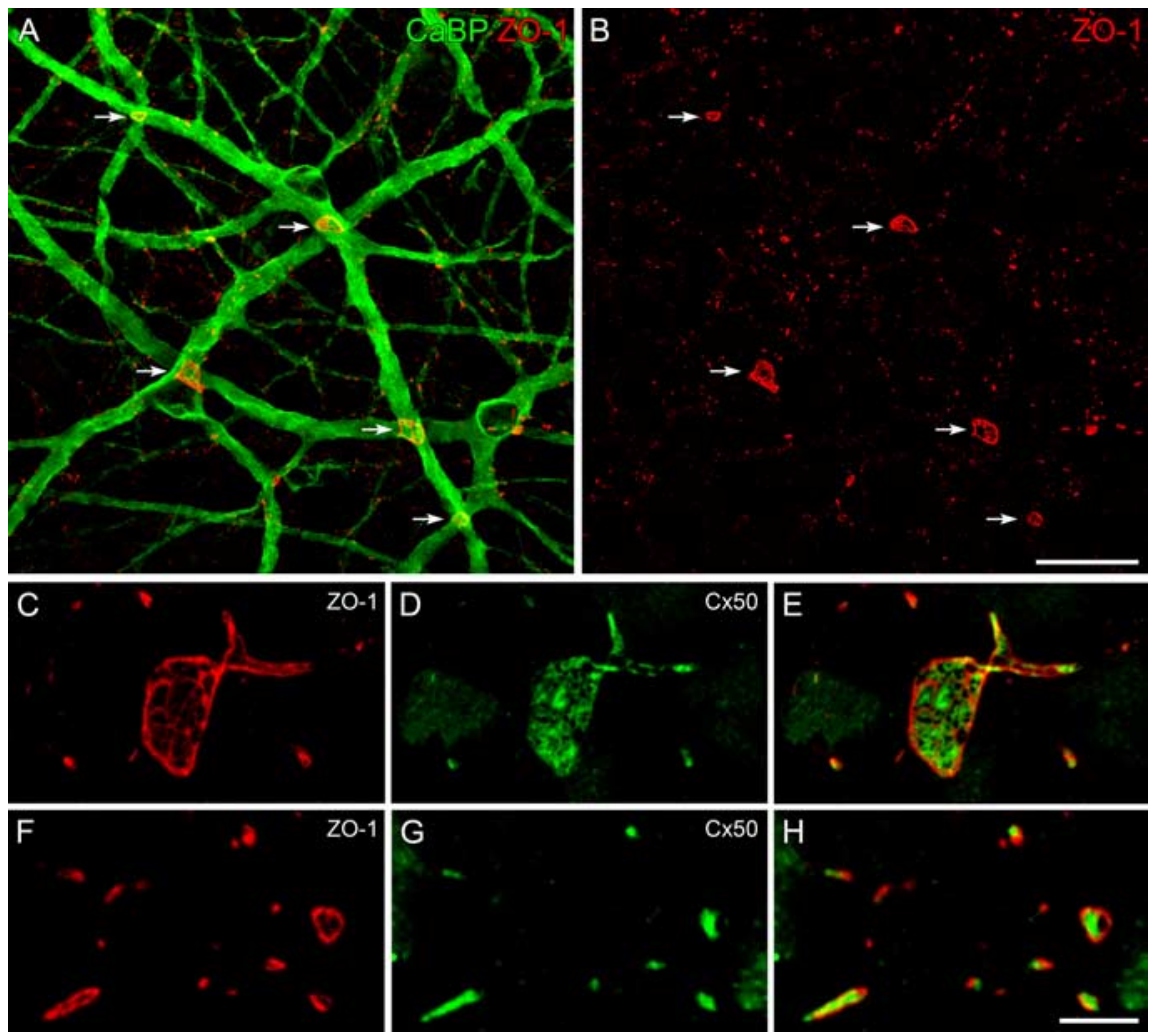

Figure 2. Z Z-1 is expressed by A-type horizontal cells (HCs) in rabbit retina and forms margins around $\mathrm{Cx} 50$-containing plaques. $A, B$, Whole-mounted rabbit retina labeled with antibodies against $20-1$ and calbindin (CaBP), which stains A-type HCs. Z0-1 immunoreactivity appears as punctate staining and large plaques (arrows). $\mathbf{C}-\boldsymbol{H}$, Whole-mounted rabbit retina immunostained for Z0-1 and $\mathbf{C}$ 50. $\boldsymbol{C}-\boldsymbol{E}$ show a large 20 - 1 -immunoreactive plaque as shown in $\boldsymbol{B}$. $\boldsymbol{F}-\boldsymbol{H}$, The spatial arrangement of connexin clusters surrounded by Z0-1 also occurs at smaller gap junctions. Scale bars: (in $B) A, B, 25 \mu \mathrm{m}$, (in $\boldsymbol{H}) \mathbf{C}-\boldsymbol{H}, 5 \mu \mathrm{m}$ 

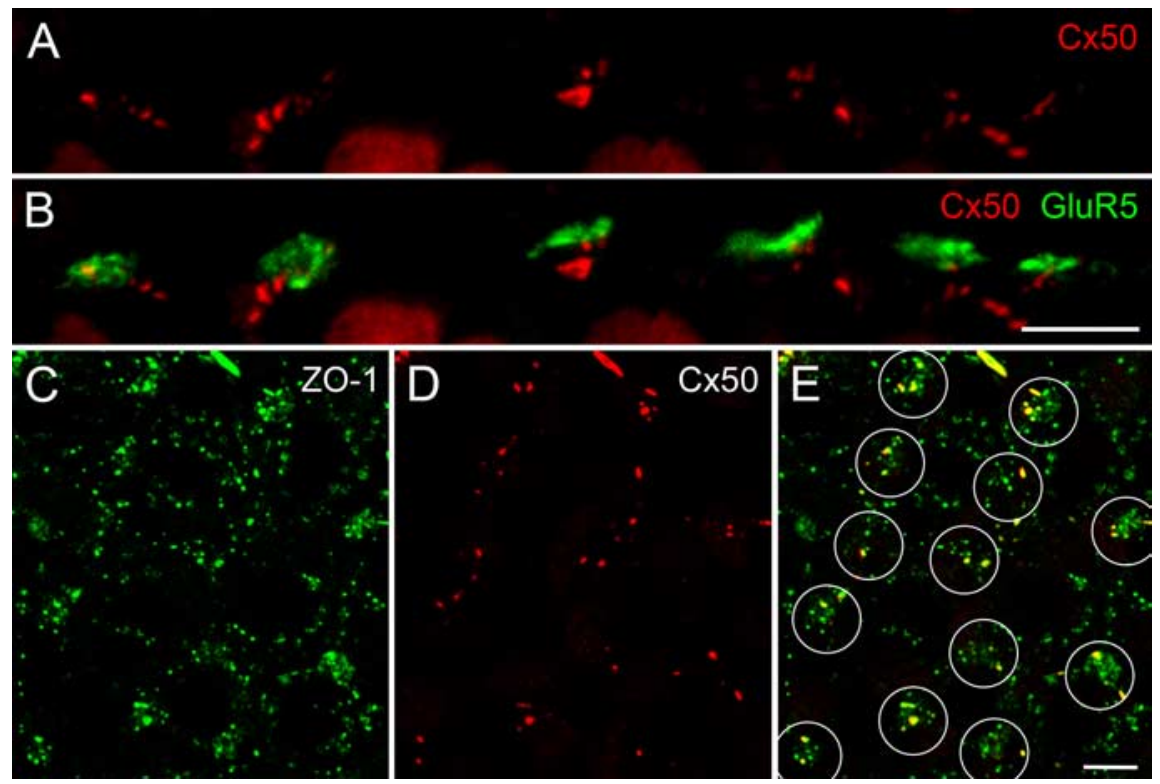

Figure 3. Cx50 and Z0-1 are colocalized beneath cone pedicles in rabbit retina. $\boldsymbol{A}, \boldsymbol{B}$, Vertical cryostat section double labeled for Cx50 and the kainate receptor subunit GluR5. GluR5 is expressed on the tips of OFF bipolar cells and was used to label the base of the cone pedicles. Cx50 is loosely clustered beneath the cone pedicles. In addition, the Cx50 antibody faintly labels some somata in the INL which appear partially at the lower edge of the figure. $\boldsymbol{C}-\boldsymbol{E}$, Whole-mounted rabbit retina immunostained for Z0-1 and Cx50. At a level slightly distal to the large 20-1 plaques, 20-1 staining appears more punctate and sometimes clustered. The merged image of Z0- 1 and $C \times 50$ staining in $\boldsymbol{E}$ shows that all $C \times 50$ puncta are colocalized with $20-1$ and that ZO- 1 is clustered with Cx50 at the cone pedicles (circled). Scale bars: $5 \mu \mathrm{m}$.

staining pattern of $\mathrm{Cx} 50$ and $\mathrm{CaBP}$ as shown recently in the rabbit retina by O'Brien et al. (2006) (their Fig. 4), suggesting that ZO-1 may interact with $\mathrm{Cx} 50$ in these cells.

Figure $2 C-E$ shows a gap junction in the OPL of a rabbit retina double labeled for ZO-1 and Cx50. This staining confirmed an association of the two proteins at the gap junctions between A-type horizontal cell dendrites. Furthermore, the huge size of these junctions allowed a good resolution of the spatial relationship between the labeled connexins and ZO-1. In fact, only a fraction of Cx50- and ZO-1-immunoreactive staining was directly colocalized. ZO-1 appeared instead to form margins around the connexin staining and to cross the gap junction with a grid-like structure as soon as the gap junction exceeds a certain size. The spatial arrangement of connexin clusters surrounded by ZO-1 staining could also be observed at smaller plaques (Fig. $2 \mathrm{~F}-H$ ).

\section{Spatial relationship of ZO-1 to $\mathrm{Cx} 50$ and $\mathrm{Cx} 57$ on horizontal cells of rabbit and mouse}

We compared rabbit and mouse retinas to investigate ZO-1 and its possible association with gap junctions beneath the cone pedicles. In the rabbit retina, Cx50 expressed by A-type horizontal cells was reported to cluster at the cone pedicles [O'Brien et al. (2006), their Fig. 11G]. We confirmed this finding on vertical sections of the rabbit retina (Fig. $3 A, B$ ) and could show, in whole-mounted specimen, that all Cx50-immunoreactive puncta were colocalized with the clustered $\mathrm{ZO}-1$ at the cone pedicles (Fig. 3C-E). The colocalization of the ZO-1 clusters with Cx50 on the horizontal cell dendrites occurred at a distance of $\sim 1-2 \mu \mathrm{m}$ from the cone pedicle base. This is the site where the horizontal cell dendrites converge before invaginating the cone pedicle. Most, if not all, of the ZO-1-immunoreactive puncta which were not colocalized with $\mathrm{Cx} 50$ were located at Cx36containing gap junctions (see below; supplemental Fig. $1 D-F$, available at www.jneurosci.org as supplemental material). How- ever, we cannot exclude that the unidentified connexin of the B-type horizontal cell dendrites is also associated with $\mathrm{ZO}-1$ beneath cone pedicles.

The mouse has only one type of horizontal cell, of the axon-bearing B-type morphology (Suzuki and Pinto, 1986; Peichl and González-Soriano, 1994). Figure $4 A-C$ shows the localization of $\mathrm{ZO}-1$ immunoreactivity on the dendrites of a Neurobiotin-injected horizontal cell network. Like in rabbit, ZO-1 clusters were colocalized with horizontal cell dendrites beneath the cone pedicle base.

Recently, it was shown that Cx57 is responsible for the electrical coupling of mouse horizontal cells (Hombach et al., 2004; Shelley et al., 2006) and Ciolofan et al. (2007) investigated the association of ZO-1, Cx36, and Cx57 in the mouse OPL. Beneath cone pedicles, they found densely clustered ZO-1 but no Cx57 expression, and hence no overlap between $\mathrm{ZO}-1$ and Cx57. However, Janssen-Bienhold et al. (2009) found Cx57 expression on both dendrites (dendro-dendritic gap junctions) and axon terminals (axo-axonal gap junctions) of mouse horizontal cells. Therefore, we reinvestigated the expression of $\mathrm{Cx} 57$ and its association with $\mathrm{ZO}-1$ in the mouse OPL. We used PSD-95 as a marker for photoreceptor terminals (Koulen et al., 1998). Double-labeling experiments with Cx57 and PSD-95 on vertical cryosections revealed $\mathrm{Cx} 57$-immunoreactive puncta clearly localized postsynaptic to rod spherules and cone pedicles (Fig. 4D-F). All Cx57-immunoreactive clusters found beneath cone pedicles (dendro-dendritic gap junctions) were exclusively colocalized with ZO-1, whereas Cx57 immunostaining beneath rods in the distal OPL (axo-axonal gap junctions) was not associated with ZO-1 (Fig. 4G-I).

ZO-1-immunoreactive puncta at the level of rod spherules were located at $\mathrm{Cx} 36$-containing gap junctions. The same holds true for the ZO-1 puncta beneath the cone pedicles, which were not colocalized with Cx57 (supplemental Fig. $1 A-C$, available at www.jneurosci.org as supplemental material). It has been shown previously that $\mathrm{ZO}-1$ colocalizes with $\mathrm{Cx} 36$ in the OPL of the mouse retina (Ciolofan et al., 2007). Here, Cx36 forms gap junctions between dendritic tips of OFF cone bipolar cells and between photoreceptors (for review, see Söhl et al., 2005). We confirmed the finding of Ciolofan et al. (2007) in the mouse retina, and double labeling of ZO-1 and Cx36 in rabbit (supplemental Fig. $1 D-F$, available at www.jneurosci.org as supplemental material) and monkey retinas (see below; Fig. 6J-L) yielded the same results.

In the rabbit retina, $\mathrm{Cx} 57$ is expressed on the axon terminals of B-type horizontal cells (Pan et al., 2007). As expected, ZO-1 was not colocalized with $\mathrm{Cx} 57$ (Fig. $4 \mathrm{~J}-\mathrm{L}$ ), which is comparable to the noncolocalization of ZO-1 and $\mathrm{Cx} 57$ in the distal part of the mouse OPL.

\section{ZO-1 localization at cone pedicles of the macaque monkey retina}

We used the monkey retina to investigate more precisely the expression pattern of the clustered ZO-1 in the OPL, and counterstained ZO-1 with antibodies labeling different cell types and 

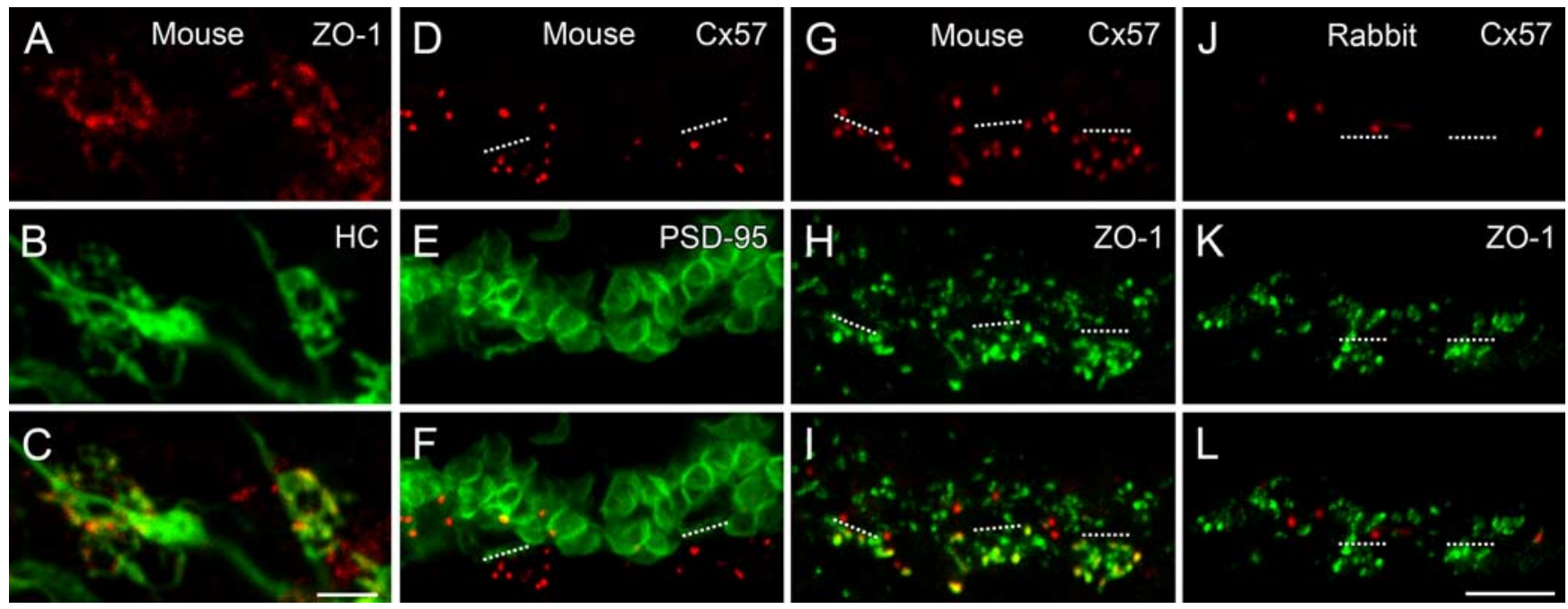

Figure 4. ZO-1 is expressed on horizontal cell (HC) dendrites in mouse retina and colocalized with $\mathrm{Cx} 57$ at dendritic sites. It is not located on $\mathrm{HC}$ axon terminals in mouse and rabbit retinas. $\mathrm{A}-\mathrm{C}$, Whole-mounted mouse retina labeled for Z0-1 after microinjection of Neurobiotin into a HC. The images show an optical section through the OPL slightly beneath the dendritic tips of the HCs, where the Z0-1 puncta beneath two cone pedicles are in focus. $\boldsymbol{D}-\boldsymbol{F}$, Double labeling of the photoreceptor terminals with PSD-95 and $\mathbf{C} 57$ in vertical sections of the mouse retina. The bases of two cone pedicles are marked by dashed lines in $\boldsymbol{D}$ and $\boldsymbol{F}$. $\mathbf{G}-\boldsymbol{I}$, Vertical sections of mouse retina immunostained for $\mathrm{C} \times 57$ and Z0-1. Three putative pedicles can be identified and are marked by dashed lines. $J-L$, Double labeling of $\mathrm{Cx} 57$ and $Z 0-1$ in the rabbit retina. (x57 staining is only found above the cone pedicles (dashed lines). Scale bars: (in $C) A-C$, (in $L$ ) $D-L, 2 \mu \mathrm{m}$.
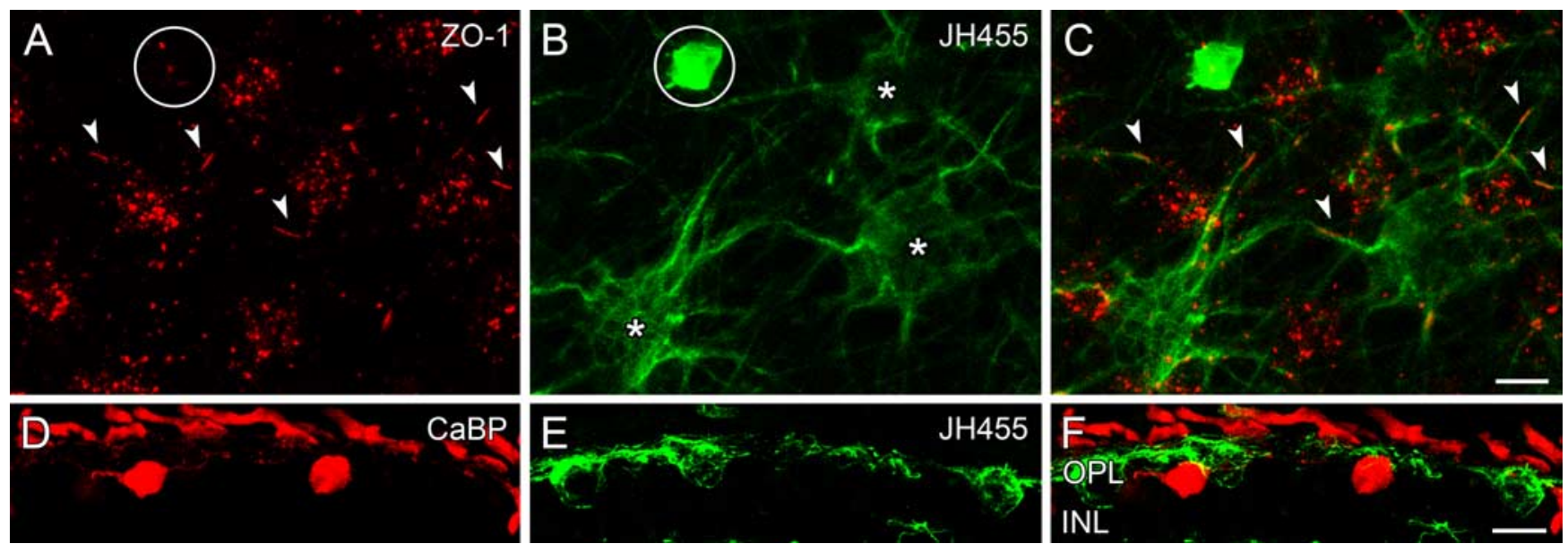

Figure 5. Z- Z-1 is expressed by $\mathrm{H} 1$ horizontal cells (HCs) in monkey retina. $A-C$, Whole-mounted macaque monkey retina immunostained for Z0-1 and S-opsin with the JH455 S-opsin antibody. One short-wavelength-sensitive (S)-cone pedicle is labeled by S-opsin (circled). 20-1 staining is strongly reduced at the S-cone pedicle compared with the dense clustering at medium- and long-wavelength-sensitive cone pedicles. The JH455 antibody also cross-reacts with cytoskeletal filaments of dendrites and cell bodies (asterisks) of H1 HCs. All string-like Z0-1 immunoreactivity (arrowheads) is confined to H1 dendrites. D-F, Vertical cryostat section double labeled for calbindin (CaBP) and JH455 anti-S-opsin. D, CaBP labels cone photoreceptors, bipolar cells, and H2 cells in the outer monkey retina. Two labeled $\mathrm{H} 2$ cell bodies are shown. $\boldsymbol{E}$, Besides its specific staining of short-wavelength-sensitive cones, the antibody against $\mathrm{S}$-opsin cross-reacts with cellular structures of HC cell bodies and dendrites. The image shows dense staining in the OPL and three large cell bodies at the distal border of the INL. $F$, None of the S-opsin-immunoreactive HCs are positive for CaBP. Their overall morphology, the larger diameter of their cell bodies compared with $\mathrm{H} 2$ cells, and the fact that they are negative for CaBP provide good evidence that the S-opsin antibody labels H1 cells. Scale bars: (in $\boldsymbol{C}) \boldsymbol{A}-\boldsymbol{C}, 5 \mu \mathrm{m}$, (in $\boldsymbol{F}) \mathbf{D}-\boldsymbol{F}, 10 \mu \mathrm{m}$.

synaptic components of gap junctions and glutamatergic synapses.

In the monkey retina, there are also two types of horizontal cells, $\mathrm{H} 1$ and $\mathrm{H} 2$ cells. The dendritic tips of $\mathrm{H} 1$ cells contact medium- and long-wavelength-sensitive (M- and L-) cone pedicles, while short-wavelength-sensitive ( $\mathrm{S}$-) cone pedicles are only sparsely contacted. The dendritic tips of $\mathrm{H} 2$ cells preferentially contact $\mathrm{S}$-cone pedicles but have additional contacts with all cones within their dendritic field (Dacey et al., 1996; Goodchild et al., 1996). Both horizontal cell types have axons: the H1 cell axon terminal contacts rods exclusively and the $\mathrm{H} 2$ axon terminal has only sparse contacts to cone pedicles (Kolb et al., 1980). Figure $5 A-C$ shows the ZO- 1 staining in the OPL of the monkey retina, counterstained with antibodies against S-opsin. The ZO-1 staining in the whole-mounted retina revealed string-like plaques and further immunoreactive puncta between the clustered regions at putative cone pedicles (Fig. $5 A$ ). At the location of the S-cone pedicle, ZO-1 expression was strongly reduced compared with $\mathrm{M}$ - and L-cone pedicles, which indicated expression of $\mathrm{ZO}-1$ by $\mathrm{H} 1$ cells. In addition to the specific labeling of S-cones, the JH455 S-opsin antibody cross-reacted with filaments of the cytoskeleton in dendrites and cell bodies of $\mathrm{H} 1$ horizontal cells in the macaque monkey retina (Fig. 5D-F). However, the cross-reactivity of this antibody, together with the ZO-1 staining, show that all stringlike $\mathrm{ZO}-1$ plaques were confined to dendrites of the $\mathrm{H} 1$ horizontal cell. 

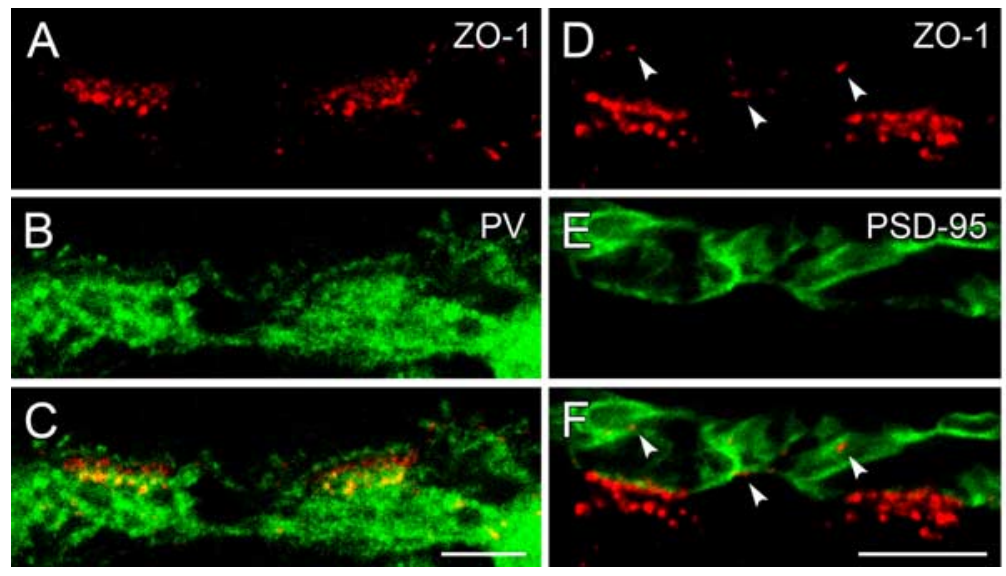
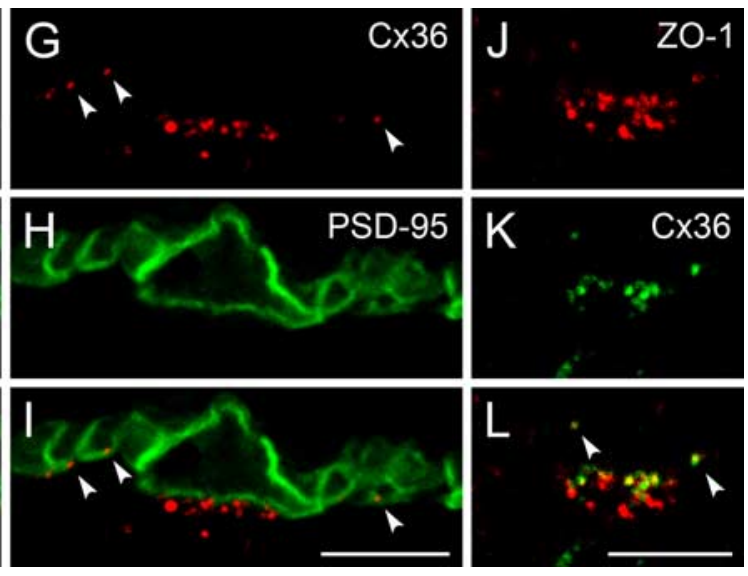

Figure 6. Z0-1 colocalizes with (X36 in the OPL of monkey retina. $\boldsymbol{A}-\boldsymbol{C}$, Single optical slice of a vertical section immunostained for Z0-1 and parvalbumin (PV), which labels all horizontal cells (HCs). Z0-1 is clustered in two bands at two cone pedicles each. The lower bands are colocalized with PV at the level of the desmosome-like junctions, while the upper bands are situated between the desmosome-like junctions and the invaginating tips of HC dendrites. D-F, Projection of an image stack of vertically sectioned retina stained for Z0-1 and the photoreceptor terminals, labeled by antibodies against the postsynaptic density protein PSD-95. Two cone pedicles and the surrounding rod spherules are shown. The arrowheads point to Z0-1 puncta in the distal OPL, which are all closely associated with the membranes of rod spherules. G-I, Double labeling of (x36 and PSD-95. Cx36 is expressed at the cone pedicle base and at rod spherules (arrowheads). J-L, The immunostaining of 20-1 and (x36 at a single cone pedicle shows that they are colocalized at the pedicle base and at rod spherules (arrowheads). Scale bars: $5 \mu \mathrm{m}$.

ZO-1 was clustered as two distinct bands at the cone pedicle base of the monkey retina, and further immunoreactive puncta appeared in more distal and proximal parts of the OPL (Fig. $6 A-F)$. As we had observed in the other species, the lower ZO-1 band was colocalized with horizontal cell dendrites (Fig. 6A-C), where they form desmosome-like junctions with each other and where different ionotropic GluR subunits have been identified as postsynaptic elements of chemical synapses (Haverkamp et al., 2000). The upper band of ZO-1-immunoreactive clusters, which was located just above the level of the desmosome-like junctions, was not associated with horizontal cell processes. The remaining ZO-1 puncta in the proximal OPL were localized on either horizontal cell dendrites or cell bodies. Further puncta in the distal OPL were found slightly beneath the invaginating tips of horizontal cell axon terminals. Double labeling of ZO-1 and PSD-95 revealed that the upper band of ZO-1 coincided with the cone pedicle base (Fig. $6 D-F$ ), whereas the puncta in the distal OPL were all associated with rod spherules (arrowheads). To find out whether ZO- 1 at the pedicle base and at the level of rod spherules is associated with Cx36-containing gap junctions, as in mouse and rabbit, we first analyzed the expression pattern of $\mathrm{Cx} 36$ in the primate retina (Fig. $6 G-I$ ). As expected, Cx36-immunoreactive puncta were found at the cone pedicle base and associated with rod spherules. Double-labeling experiments with ZO-1 and Cx36 supported the results from mouse and rabbit retinas: the upper band of ZO-1 at the pedicle base and the puncta associated with the membranes of rod spherules were all colocalized with Cx36 (Fig. 6J-L).

The connexins of primate horizontal cells are not yet known and therefore equivalent double-labeling experiments with ZO-1, as presented before in mouse and rabbit, were not feasible. To rule out a function of ZO-1 at the level of the desmosome-like junctions in the primate retina other than an association with gap junctions, we performed double-staining experiments of ZO-1 and different GluR subunits. Although ZO-1 expression has now been shown on horizontal cells at the same level with the desmosome-like junctions, it was not colocalized with the AMPA receptor subunits GluR2/3 (Fig. 7A-C). GluR2/3 and GluR4 are expressed at the dendritic tips of horizontal cells and at the desmosome-like junctions (Haverkamp et al., 2001a). In retinal whole mounts, ZO-1 and GluR2/3 clusters were found in close apposition (Fig. $7 D-F)$. The same results were obtained by double labeling ZO-1 and GluR4 (Fig. 7G-H). The kainate receptor subunits GluR6/7 are also expressed at the desmosome-like junctions of horizontal cells, and in addition, on dendritic tips of OFF bipolar cells at the cone pedicle base (Haverkamp et al., 2001b). The results of double-labeling experiments with ZO-1 and GluR6/7 were similar to those shown with GluR2/3 and GluR4. The large ZO-1 puncta were not colocalized, but closely associated with GluR6/7 at the level of desmosome-like junctions (Fig. $7 J-L$ ). Since in rabbit retina, clusters of GluR2/3 and GluR4 subunits were also found beneath the cone pedicles (Pan and Massey, 2007), a close association to Cx50/ZO-1 was very likely, and was confirmed in double-labeled material with GluR2/3 and ZO-1 (data not shown). In summary, ZO-1 and the GluR subunits at the desmosome-like junctions were not randomly arrayed, but closely associated.

To further investigate the close association of the GluR subunits with ZO-1, we did preembedding and postembedding immunocytochemistry and electron microscopy. Figure $8 \mathrm{~A}-\mathrm{C}$ shows results of the localization of GluR2/3 and GluR4 at the desmosome-like junctions of macaque retina, using postembedding immunoelectron microscopy. Both sides of the junctions were often decorated with gold particles, suggesting that AMPA receptors are expressed by both members of this junction. These results show that the AMPA receptors are not distributed all over the two postsynaptic processes, as one might deduce from preembedding immunolabeling (Haverkamp et al., 2001), but are aggregated directly at the desmosome-like structure. Unfortunately, we were not able to produce ZO-1 postembedding immunolabeling. However, our serially sectioned preembedding material showed that the center zone of immunoreactivity at these sites was often associated with the contiguous plasmamembrane and not directly with the desmosome-like structure itself. The two examples in Figure 8, $D$ and $E$, show putative gap junctions (white arrows) adjacent to desmosome-like junctions (arrowheads).

\section{Discussion}

This study describes the spatial relationship of ZO-1 to different connexins and glutamate receptors in the OPL of rabbit, mouse, and monkey retina. Our data show that the spatial organization 

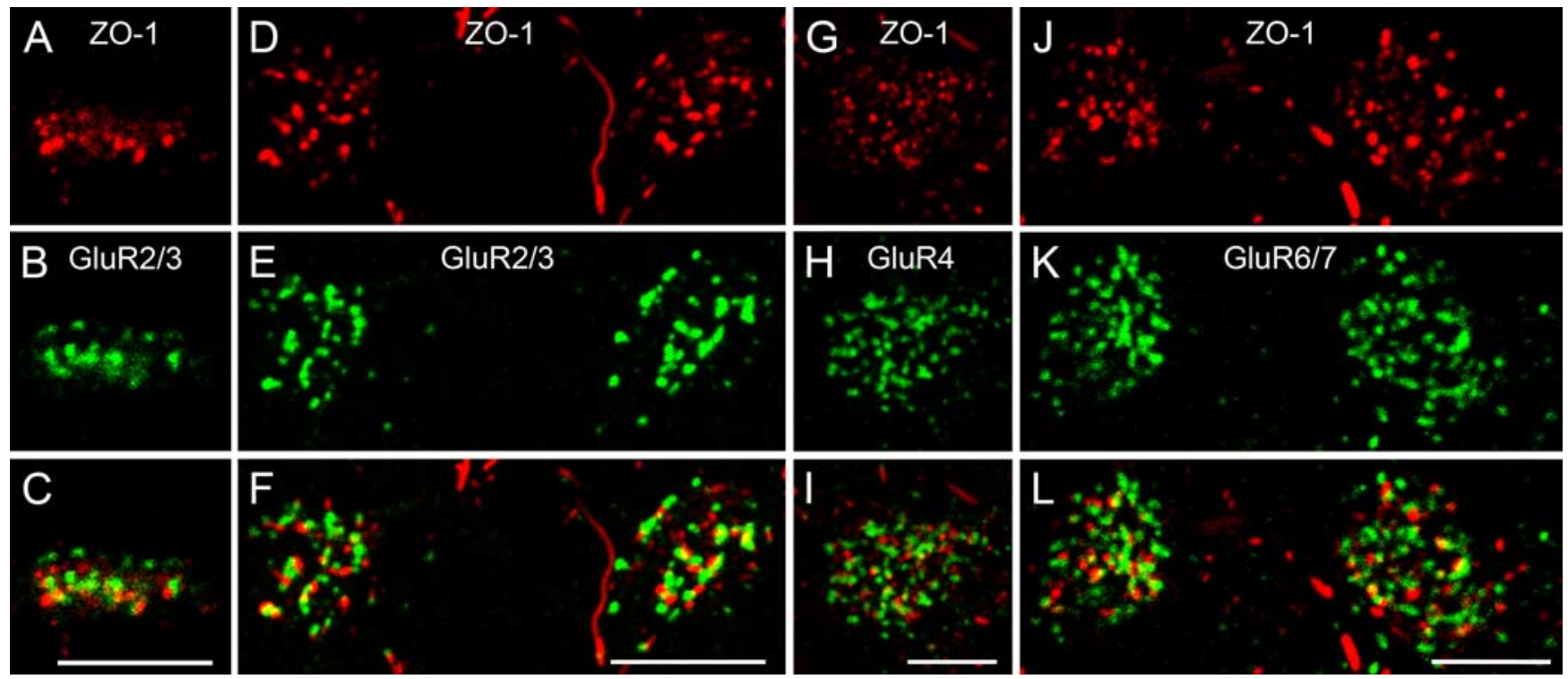

Figure 7. Z0-1 at the level of the desmosome-like junctions is closely associated with GluRs in monkey retina. A-C, Vertical cryostat section double labeled for Z0-1 and the AMPA receptor subunits GluR2/3. A single cone pedicle is shown, at which the GluR2/3 staining occurs as two bands. The upper band is located at the tips of invaginating horizontal cell dendrites, the lower one at the desmosome-like junctions. $\boldsymbol{D}-\boldsymbol{I}$, Horizontal view of the desmosome-like junctions labeled for Z0-1, GluR2/3 (D-F), and GluR4 (G-I) beneath cone pedicles in whole-mounted retina. Instead of a random distribution, the large Z0-1 puncta always appear in very close vicinity to the GluR puncta. $J-L$, Immunostaining of Z0-1 and the kainate receptor subunits GluR6/7 at the level of the desmosome-like junctions of two cone pedicles. Most of the Z0-1 puncta are closely associated with GluR6/7. Scale bars: $5 \mu \mathrm{m}$.

of these proteins beneath the cone pedicles is very similar among mammalian species (Fig. 9A). Cx36 is expressed between photoreceptors and between dendrites of OFF bipolar cells (Feigenspan et al., 2004). GluRs are expressed in close association to gap junctions at the desmosome-like junctions. Additionally, the expression of ZO-1 in horizontal cells and the association with $\mathrm{Cx} 50$ or $\mathrm{Cx} 57$ is cell type specific: In monkey, ZO-1 is clustered beneath cone pedicles on $\mathrm{H} 1$ horizontal cell dendrites, but not on $\mathrm{H} 2$ cells. So far, 21 connexin genes have been described in the human genome (Söhl and Willecke, 2003); however, except for Cx36 (Massey, 2008) no other connexin protein has been detected in monkey retina to date. In rabbit, $\mathrm{ZO}-1$ is associated with $\mathrm{Cx} 50$ on A-type horizontal cell dendrites. B-type cells express $\mathrm{Cx} 57$ on their axon terminals (Pan et al., 2007), which is not associated with ZO-1. The connexin of dendrites of B-type cells is not yet known. In mouse, Cx57 is expressed on both dendrites and axon terminals of the horizontal cells (Janssen-Bienhold et al., 2009). However, ZO-1 is only expressed and colocalized with $\mathrm{Cx} 57$ on the horizontal cell dendrites beneath the cone pedicles, and not on the axon terminals.

\section{Gap junction architecture}

An important finding of our study is that ZO- 1 is not colocalized with Cx50 at the giant gap-junctional plaques of A-type horizontal cells. It appears to form a kind of tight or adherens junction around the
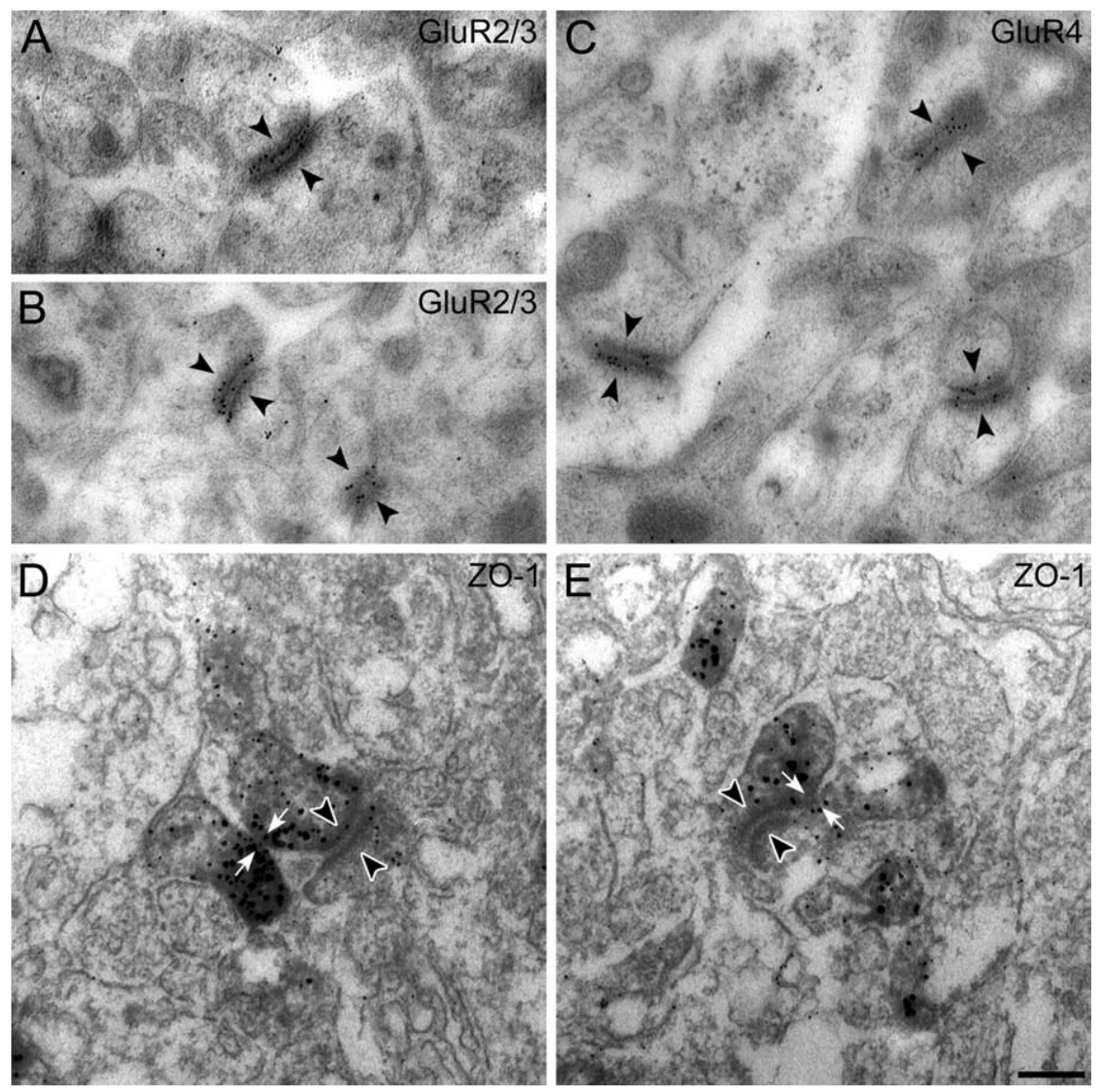

Figure 8. Electron micrographs of vertical sections through the synaptic complex beneath cone pedicles of the macaque monkey retina that were immunolabeled using postembedding $(\boldsymbol{A}-\boldsymbol{C})$ and preembedding methods $(\boldsymbol{D}, \boldsymbol{E})$. $\boldsymbol{A}, \boldsymbol{B}, \mathrm{GluR2} / 3$ label is located at both sides of the desmosome-like junctions (arrowheads) beneath the cone pedicle. $C$, Both sides of three desmosome-like junctions are labeled for GluR4 (arrowheads). D, E, Preembedding immunolabeling of Z0-1 beneath the cone pedicle. The white arrows point to putative gap junctions directly adjacent to desmosome-like junctions (arrowheads). Scale bar: $0.2 \mu \mathrm{m}$. 


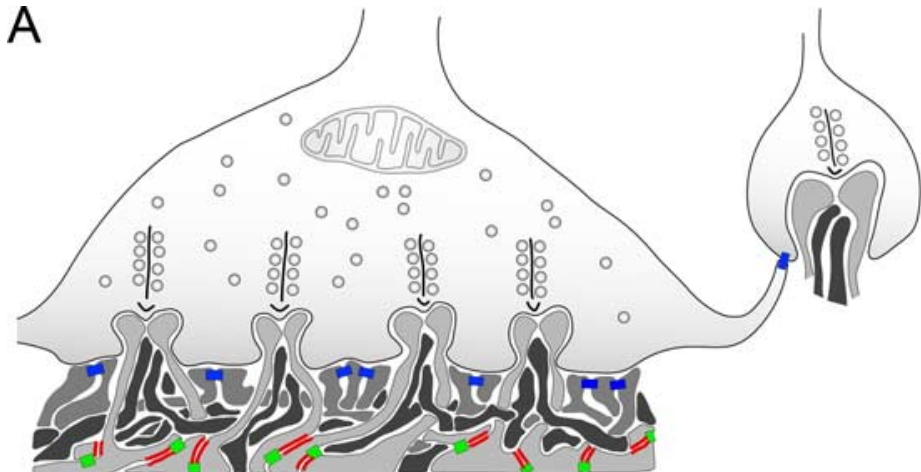

B

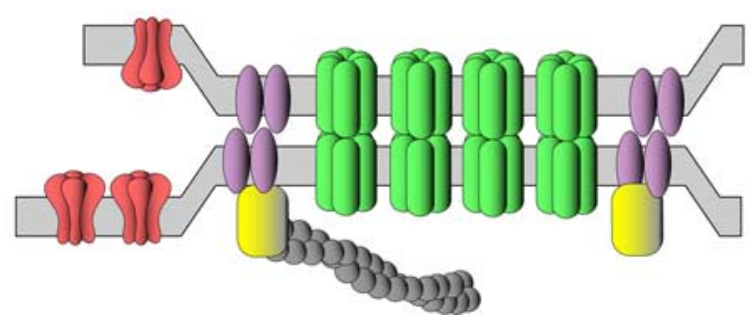

Figure 9. Schematic illustration of two photoreceptor terminals, gap junctions, and their synaptic organization. $\boldsymbol{A}$, Vertical view of a cone pedicle and a neighboring rod spherule. Within the terminals, ribbons with tethered vesicles are depicted. Corresponding invaginating elements of postsynaptic cells are formed by dendritic tips of horizontal cells and ON bipolar cells. OFF bipolar cells making flat contacts to the cone pedicles are electrically coupled by Cx36-containing gap junctions (blue rectangles), which are also formed between photoreceptors. The red bars beneath the pedicle indicate desmosome-like junctions between horizontal cells, where ionotropic GluRs are expressed. Gap junctions are also formed between their dendrites (green rectangles) at the same level and in close vicinity to the desmosome-like junctions. $\boldsymbol{B}$, Model of the spatial arrangement of proteins at the investigated synapses in the OPL. The gap junction is closely associated with the GluRs of desmosome-like junctions and surrounded by tight or adherens junctions formed by Z0-1 and transmembrane proteins. 20-1 links these proteins - and most likely not the connexins - to the cytoskeleton.

gap junctions instead of interacting with Cx50 directly. This arrangement might be comparable with electron microscopic observations in the cat retina (Kolb, 1977), where horizontal cell gap junctions are bounded by macula adherens junctions. Also, the organization of gap junctions bordered by tight junctions was shown in electron microscopic studies of rabbit corneal endothelial cells (Raviola et al., 1980).

ZO-1 was originally identified as a tight junction-associated protein (Stevenson et al., 1986) and it belongs to the family of membrane-associated guanylate kinase homologs (MAGUKs) (for review, see González-Mariscal et al., 2000). More recently, ZO-1 was found to codistribute with gap junctions at cell-cell contacts, and to interact with $\mathrm{Cx} 31.9, \mathrm{Cx} 43, \mathrm{Cx} 45, \mathrm{Cx} 46$, and Cx50 via its second PDZ domain (for review, see Giepmans, 2004) and with Cx35/36 via the first PDZ domain (Li et al., 2004; Flores et al., 2008).

Our results suggest that $\mathrm{ZO}-1$ functions more like a tight junction protein rather than interacting directly with $\mathrm{Cx} 50, \mathrm{Cx} 57$, and Cx36: although Cx57 lacks a classical C-terminal PDZ domainbinding motif, ZO-1 and Cx57 are colocalized at the dendrodendritic gap junctions in mouse horizontal cells. Furthermore, in $\mathrm{C} \times 36^{-1-}$ mice, labeling of ZO-1 was only slightly reduced, whereas the absence of $\mathrm{Cx} 36$ resulted in a large reduction of $\mathrm{ZO}-2$ and ZONAB (ZO-1-associated nucleic acid-binding protein) (Ciolofan et al., 2006). These results suggest a direct interaction of Cx36 with ZO-2 and/or ZONAB rather than with ZO-1.

Based on our results, the model in Figure $9 B$ describes the composition of proteins at gap junctions in close apposition to the GluRs at desmosome-like junctions. In our view, ZO-1 does
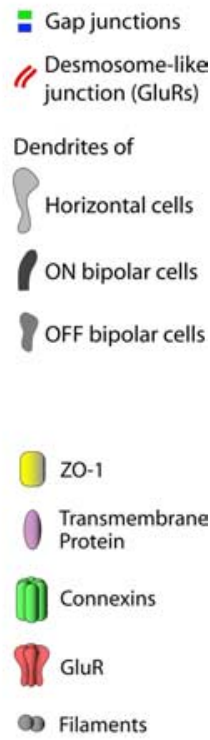

not serve as a scaffolding protein for the connexins, but it forms margins around the gap junctions, most likely associated with transmembrane proteins such as occludin, cadherins, or other junction adhesion molecules (for review, see Giepmans, 2004). At these tight or adherens junctions, ZO-1 typically links the transmembrane protein to the cytoskeleton, while the binding partner itself spans the membrane and provides for the bonding of adjacent cells.

However, assuming that ZO-1 acts as a tight or adherens junction protein around gap junctions, a direct interaction of $\mathrm{ZO}-1$ with the connexins at the outer rim of the gap junction is still possible because of its multiple binding sites. As mentioned above, $\mathrm{ZO}-1$ binds to the connexins via its first or second PDZ domain. But the interactions with actin and occludin, for instance, occur via its GUK domain and its proline-rich C-terminal half, respectively (Fanning et al., 1998). Hence, ZO-1 could potentially bind to all three of these proteins simultaneously at those sites where the two types of junctions adjoin.

This kind of assembly could also explain the results of other studies, where a direct interaction of ZO-1 with different retinal connexins has been shown by coimmunoprecipitation and pull-down assays (Li et al., 2004, 2008). In addition, Li et al. (2008) presented data from electron microscopic (FRIL) experiments, indicating a coscaffolding of $\mathrm{Cx} 45$ and $\mathrm{Cx} 36$ by ZO-1 at bihomotypic gap junctions in the IPL. In their model of gap junctional architecture, $\mathrm{ZO}-1$ intracellularly covers the whole area of the gap junction. In contrast, similar experiments in their study from 2004 show ZO-1 only at the outer rims of $\mathrm{Cx} 36$-containing gap junctions in the IPL, which in turn supports our model. It remains unclear whether these results describe varying modes of ZO-1 interaction with proteins at different gap junctions, and further investigation is needed to elucidate the structural composition of gap junctions and their associated proteins.

\section{Modulation of horizontal cell coupling}

Horizontal cell coupling is one mechanism that allows these cells to collect light information over a large area of the retina and to adjust the gain of photoreceptors to different levels of ambient light (for review, see Kamermans and Spekreijse, 1999). The coupling is modulated by ambient light in a triphasic manner: at low and high levels, coupling is reduced, while at intermediate light levels, coupling is maximized (Xin and Bloomfield, 1999). Various studies have shown that horizontal cell coupling is reduced by endogenous release or application of dopamine. The activation of $\mathrm{D}_{1}$ receptors leads to an increase in cAMP, which in turn leads to the phosphorylation of connexins by protein kinase A (Piccolino et al., 1984; Lasater, 1987; Hampson et al., 1994; McMahon, 1994; $\mathrm{He}$ at al., 2000). Another pathway for modulation of gap junction is via nitric oxide, which activates soluble guanylate cyclase, leading to an increase in cGMP and a reduction in gap-junctional conductance (Lu and McMahon, 1997; Pottek et al., 1997; Xin 
and Bloomfield, 2000). Both pathways lead to reduced horizontal cell coupling, but work through different mechanisms, suggesting several distinct pathways for dark- and light-induced modulation. Endogenous dopamine release is increased by light and during prolonged darkness at night (Weiler et al., 1997), but what happens at low light levels or darkness during the day?

We found two kinds of gap junctions associated with ZO-1: giant gap-junctional plaques at horizontal cell dendritic crossings in the OPL, and small gap-junctional plaques beneath the cone pedicle, where the dendrites of horizontal cells converge. The small gap junctions were in close relationship with clusters of GluRs at the desmosome-like junctions in monkey and rabbit retinas, indicating that calcium may play a role in regulating gapjunctional permeability. In darkness, horizontal cells are depolarized and calcium enters the cell via calcium-permeable AMPA receptors and voltage-gated calcium channels (Solessio and Lasater, 2002; Schubert et al., 2006). In the past, the role of calcium in coupling regulation has been discussed controversially (Spray et al., 1982; Lazrak and Peracchia, 1993), but calcium was recently found to regulate the permeability of $\mathrm{Cx} 43$ in a calmodulindependent manner (Lurtz and Louis, 2007). Therefore, calcium entering through discrete sites, such as the GluRs at desmosomelike junctions, may regulate gap-junctional coupling during conditions of retinal adaptation which are not triggered by dopamine.

A comparable system can be found at synapses formed by club endings of auditory afferents onto teleost Mauthner cells. These are mixed synapses where glutamatergic synapses work in parallel with gap junctions formed by Cx35 (for review, see Pereda et al., 2004). The conductance of these electrical synapses is regulated by dopamine and NMDA receptor activation, and different pathways are used: cAMP-dependent in the case of dopamine, and calcium-dependent in the case of NMDA receptor. Mixed synapses have also been identified in rat spinal cord and inferior olive (Rash et al., 1996; Pereda et al., 2004). Pereda et al. (2004) proposed that GluR-mediated modulation of electrical synapses is not limited to mixed synapses and can be found where chemical synapses are close to gap junctions. In contrast to the paracrine action of dopamine released from somewhat distant varicosities, modulation by GluRs is more spatially restricted, differentially controlling the conductance of nearby gap junctions. According to our data, we suggest that the giant horizontal cell gap junctions are modulated by dopamine, whereas the small dendritic gap junctions beneath the cone pedicles are modulated by calcium and possibly also by dopamine.

\section{References}

Baude A, Nusser Z, Roberts JDB, Mulvihill E, McIlhinney RAG, Somogyi P (1993) The metabotropic glutamate receptor (mGluRla) is concentrated at perisynaptic membrane of neuronal subpopulations as detected by immunogold reaction. Neuron 11:771-787.

Bloomfield SA, Miller RF (1982) A physiological and morphological study of the horizontal cell types of the rabbit retina. J Comp Neurol 208:288-303.

Bloomfield SA, Xin D, Persky SE (1995) A comparison of receptive field and tracer coupling size of horizontal cells in the rabbit retina. Vis Neurosci 12:985-999.

Ciolofan C, Li XB, Olson C, Kamasawa N, Gebhardt BR, Yasumura T, Morita M, Rash JE, Nagy JI (2006) Association of connexin36 and zonula occludens- 1 with zonula occludens- 2 and the transcription factor zonula occludens-1-associated nucleic acid-binding protein at neuronal gap junctions in rodent retina. Neuroscience 140:433-451.

Ciolofan C, Lynn BD, Wellershaus K, Willecke K, Nagy JI (2007) Spatial relationships of connexin 36 , connexin 57 and zonula occludens- 1 in the outer plexiform layer of mouse retina. Neuroscience 148:473-488.
Dacey DM, Lee BB, Stafford DK, Pokorny J, Smith VC (1996) Horizontal cells of the primate retina: cone specificity without spectral opponency. Science 271:656-659.

Dacheux RF, Raviola E (1982) Horizontal cells in the retina of the rabbit. J Neurosci 2:1486-1493.

Fanning AS, Jameson BJ, Jesaitis LA, Anderson JM (1998) The tight junction protein ZO-1 establishes a link between the transmembrane protein occludin and the actin cytoskeleton. J Biol Chem 273:29745-29753.

Feigenspan A, Janssen-Bienhold U, Hormuzdi S, Monyer H, Degen J, Söhl G, Willecke K, Ammermüller J, Weiler R (2004) Expression of connexin36 in cone pedicles and OFF-cone bipolar cells of the mouse retina. J Neurosci 24:3325-3334.

Flores CE, Li X, Bennett MV, Nagy JI, Pereda AE (2008) Interaction between connexin 35 and zonula occludens- 1 and its potential role in the regulation of electrical synapses. Proc Natl Acad Sci U S A 105:12545-12550.

Giepmans BNG (2004) Gap junctions and connexin-interacting proteins. Cardiovasc Res 62:233-245.

González-Mariscal L, Betanzos A, Avila-Flores A (2000) MAGUK proteins: structure and role in the tight junction. Semin Cell Dev Biol 11:315-324.

Goodchild AK, Chan TL, Grünert U (1996) Horizontal cell connections with short-wavelength-sensitive cones in macaque monkey retina. Vis Neurosci 13:833-845.

Hampson EC, Weiler R, Vaney DI (1994) pH-gated dopaminergic modulation of horizontal cell gap junctions in mammalian retina. Proc Biol Sci 255:67-72.

Haverkamp S, Grünert U, Wässle H (2000) The cone pedicle, a complex synapse in the retina. Neuron 27:85-95.

Haverkamp S, Grünert U, Wässle H (2001a) The synaptic architecture of AMPA receptors at the cone pedicle of the primate retina. J Neurosci 21:2488-2500.

Haverkamp S, Grünert U, Wässle H (2001b) Localization of kainate receptors at the cone pedicles of the primate retina. J Comp Neurol 436:471-486.

He S, Weiler R, Vaney DI (2000) Endogenous dopaminergic regulation of horizontal cell coupling in the mammalian retina. J Comp Neurol 418:33-40.

Hombach S, Janssen-Bienhold U, Söhl G, Schubert T, Büssow H, Ott T, Weiler R, Willecke K (2004) Functional expression of connexin57 in horizontal cells of the mouse retina. Eur J Neurosci 19:2633-2640.

Janssen-Bienhold U, Trümpler J, Hilgen G, Schultz K, Pérez de Sevilla Müller L, Sonntag S, Dedek K, Dirks P, Willecke K, Weiler R (2009) Connexin 57 is expressed in dendro-dendritic and axo-axonal gap junctions of mouse horizontal cells and its distribution is modulated by light. J Comp Neurol 513:363-374.

Kamermans M, Spekreijse H (1999) The feedback pathway from horizontal cells to cones. A mini review with a look ahead. Vision Res 39:2449-2468.

Kaneko A (1971) Electrical connexions between horizontal cells in the dogfish retina. J Physiol 213:95-105.

Kolb H (1977) The organization of the outer plexiform layer in the retina of the cat: electron microscopic observations. J Neurocytol 6:131-153.

Kolb H, Mariani A, Gallego A (1980) A second type of horizontal cell in the monkey retina. J Comp Neurol 189:31-44.

Koulen P, Fletcher EL, Craven SE, Bredt DS, Wässle H (1998) Immunocytochemical localization of the postsynaptic density protein PSD-95 in the mammalian retina. J Neurosci 18:10136-10149.

Lasater EM (1987) Retinal horizontal cell gap junctional conductance is modulated by dopamine through a cyclic AMP-dependent protein kinase. Proc Natl Acad Sci U S A 84:7319-7323.

Lazrak A, Peracchia C (1993) Gap junction gating sensitivity to physiological internal calcium regardless of $\mathrm{pH}$ in Novikoff hepatoma cells. Biophys J 65:2002-2012.

Li X, Olson C, Lu S, Kamasawa N, Yasumura T, Rash JE, Nagy JI (2004) Neuronal connexin36 association with zonula occludens-1 protein (ZO-1) in mouse brain and interaction with the first PDZ domain of ZO-1. Eur J Neurosci 19:2132-2146.

Li X, Kamasawa N, Ciolofan C, Olson CO, Lu S, Davidson KG, Yasumura T, Shigemoto R, Rash JE, Nagy JI (2008) Connexin45-containing neuronal gap junctions in rodent retina also contain connexin 36 in both apposing hemiplaques, forming bihomotypic gap junctions, with scaffolding contributed by zonula occludens-1. J Neurosci 28:9769-9789.

Lu C, McMahon DG (1997) Modulation of hybrid bass retinal gap junctional channel gating by nitric oxide. J Physiol 499:689-699. 
Lurtz MM, Louis CF (2007) Intracellular calcium regulation of connexin43. Am J Physiol Cell Physiol 293:C1806-C1813.

Massey SC (2008) Circuit functions of gap junctions in the mammalian retina. In: The senses: a comprehensive reference (Basbaum AI, Kaneko A, Shepherd GM, Westheimer G, eds), pp 457-471. San Diego: Academic.

McMahon DG (1994) Modulation of electrical synaptic transmission in zebrafish retinal horizontal cells. J Neurosci 14:1722-1734.

O’Brien JJ, Li W, Pan F, Keung J, O’Brien J, Massey SC (2006) Coupling between A-type horizontal cells is mediated by connexin 50 gap junctions in the rabbit retina. J Neurosci 26:11624-11636.

Pan F, Massey SC (2007) Rod and cone input to horizontal cells in the rabbit retina. J Comp Neurol 500:815-831.

Pan F, Keung JW, Snuggs MB, Kim IB, O’Brien J, Massey SC (2007) Expression of connexin 57 by horizontal cell axon terminals in the rabbit retina. Invest Ophthalmol Vis Sci 48: E-Abstract 2848.

Peichl L, González-Soriano J (1994) Morphological types of horizontal cell in rodent retinae: a comparison of rat, mouse, gerbil, and guinea pig. Vis Neurosci 11:501-517.

Pereda AE, Rash JE, Nagy JI, Bennett MV (2004) Dynamics of electrical transmission at club endings on the Mauthner cells. Brain Res Brain Res Rev 47:227-244.

Perlman I, Ammermüller J (1994) Receptive-field size of L1 horizontal cells in the turtle retina: effects of dopamine and background light. J Neurophysiol 72:2786-2795.

Piccolino M, Neyton J, Gerschenfeld HM (1984) Decrease of gap junction permeability induced by dopamine and cyclic adenosine $3^{\prime}: 5^{\prime}$ monophosphate in horizontal cells of turtle retina. J Neurosci 4:2477-2488.

Pottek M, Weiler R (2000) Light-adaptive effects of retinoic acid on receptive field properties of retinal horizontal cells. Eur J Neurosci 12:437-445.

Pottek M, Schultz K, Weiler R (1997) Effects of nitric oxide on the horizontal cell network and dopamine release in the carp retina. Vision Res 37:1091-1102.

Rash JE, Dillman RK, Bilhartz BL, Duffy HS, Whalen LR, Yasumura T (1996) Mixed synapses discovered and mapped throughout mammalian spinal cord. Proc Natl Acad Sci U S A 93:4235-4239.

Raviola E, Goodenough DA, Raviola G (1980) Structure of rapidly frozen gap junctions. J Cell Biol 87:273-279.

Röhrenbeck J, Wässle H, Heizmann CW (1987) Immunocytochemical labelling of horizontal cells in mammalian retina using antibodies against calcium-binding proteins. Neurosci Lett 77:255-260.
Sassoè-Pognetto M, Wässle H, Grünert U (1994) Glycinergic synapses in the rod pathway of the rat retina: cone bipolar cells express the alpha 1 subunit of the glycine receptor. J Neurosci 14:5131-5146.

Schubert T, Weiler R, Feigenspan A (2006) Intracellular calcium is regulated by different pathways in horizontal cells of the mouse retina. J Neurophysiol 96:1278-1292.

Shelley J, Dedek K, Schubert T, Feigenspan A, Schultz K, Hombach S, Willecke K, Weiler R (2006) Horizontal cell receptive fields are reduced in connexin57-deficient mice. Eur J Neurosci 23:3176-3186.

Söhl G, Willecke K (2003) An update on connexin genes and their nomenclature in mouse and man. Cell Commun Adhes 10:173-180.

Söhl G, Maxeiner S, Willecke K (2005) Expression and functions of neuronal gap junctions. Nat Rev Neurosci 6:191-200.

Solessio E, Lasater EM (2002) Calcium-induced calcium release and calcium buffering in retinal horizontal cells. Vis Neurosci 19:713-725.

Spray DC, Stern JH, Harris AL, Bennett MV (1982) Gap junctional conductance: comparison of sensitivities to $\mathrm{H}$ and $\mathrm{Ca}$ ions. Proc Natl Acad Sci U S A 79:441-445.

Stevenson BR, Siliciano JD, Mooseker MS, Goodenough DA (1986) Identification of ZO-1: a high molecular weight polypeptide associated with the tight junction (zonula occludens) in a variety of epithelia. J Cell Biol 103:755-766.

Suzuki H, Pinto LH (1986) Response properties of horizontal cells in the isolated retina of wild-type and pearl mutant mice. J Neurosci 6:1122-1128.

Teranishi T, Negishi K, Kato S (1983) Dopamine modulates S-potential amplitude and dye-coupling between external horizontal cells in carp retina. Nature 301:243-246.

Wang Y, Macke JP, Merbs SL, Zack DJ, Klaunberg B, Bennett J, Gearhart J, Nathans J (1992) A locus control region adjacent to the human red and green visual pigment genes. Neuron 9:429-440.

Wässle H (2004) Parallel processing in the mammalian retina. Nat Rev Neurosci 5:747-757.

Weiler R, Baldridge WH, Mangel SC, Dowling JE (1997) Modulation of endogenous dopamine release in the fish retina by light and prolonged darkness. Vis Neurosci 14:351-356.

Xin D, Bloomfield SA (1999) Dark- and light-induced changes in coupling between horizontal cells in mammalian retina. J Comp Neurol 405:75-87.

Xin D, Bloomfield SA (2000) Effects of nitric oxide on horizontal cells in the rabbit retina. Vis Neurosci 17:799-811. 